\title{
Crop growth analysis and yield of a lignocellulosic biomass crop (Arundo donax L.) in three marginal areas of Campania region
}

\author{
Adriana Impagliazzo, Mauro Mori, Nunzio Fiorentino, Ida Di Mola, Lucia Ottaiano, \\ Donato De Gianni, Sabrina Nocerino, Massimo Fagnano
}

Department of Agriculture, University of Naples Federico II, Portici (NA), Italy

\begin{abstract}
The depletion of energy resources from fossil fuels and global warming have pushed to consider the agro-energy as one of the renewable energy sources for mitigation of climate change. In this context, agro-energy based on cultivation of energy crops in marginal lands allows to reduce competition with food crops and marginal lands abandonment, producing incomes for farmers. The aim of this work is to improve the knowledge on a promising crop (Arundo donax L.) for the production of bio-energy in marginal lands. Therefore, the behaviour of this crop was evaluated in three study areas of Campania region, under different energy inputs: two levels of nitrogen fertilisation, N100 and N50 in Sant'Angelo dei Lombardi (SA) and Bellizzi (BL). In Acerra (AC) site compost fertilisation was made to verify its effect on pollutant phytoextraction. In the last year, also crop growth analysis was done in the three sites. The results showed that giant reed confirms its adaptability to low fertility soils, allowing interesting biomass yield also in marginal lands. In more fertile environments, effect of fertilisation is not significant at least in the short term. Nevertheless, nitrogen uptake (65-130 $\left.\mathrm{kg} \mathrm{N} \mathrm{ha}^{-1}\right)$, also if lower than other highyielding crops, needs to be compensated with fertilisation to avoid depletion of soil nutrient reserves and to guarantee sustainability of this cropping system. Giant reed had a positive environmental impact, due to the improvement in soil fertility (soil organic matter and nitrogen increase) and to the mitigation of climate change
\end{abstract}

Correspondence: Adriana Impagliazzo, Department of Agriculture, University of Naples Federico II, via Università 100, 80055 Portici (NA), Italy.

Tel./Fax: +39.081.2539126.

E-mail: adriana.impagliazzo@unina.it

Key words: Giant reed; Biomass yield; Growth analysis; LAD.

Conference presentation: SIA XLIV Congress, Bologna, 2015.

Received for publication: 30 January 2016.

Revision received: 23 June 2016.

Accepted for publication: 9 July 2016.

CCopyright A. Impagliazzo et al., 2017

Licensee PAGEPress, Italy

Italian Journal of Agronomy 2017; $12: 755$

doi:10.4081/ija.2016.755

This article is distributed under the terms of the Creative Commons Attribution Noncommercial License (by-nc 4.0) which permits any noncommercial use, distribution, and reproduction in any medium, provided the original author(s) and source are credited.
(C storage in the soil). In marginal soils of Southern Italy this crop confirms an increasing trend of yield during the first 3-4 years. High productivity levels of this crop are related to the extremely high duration of the vegetative period and thus of the photosynthetic activity (from March to November in the Mediterranean area). These last are well expressed by the leaf area duration index, which is more than double than other high-yielding crops such as maize (280 vs 140 days).

\section{Introduction}

In recent years the concerns about the depletion of energy resources derived from fossil fuels have led to a greater attention on renewable energy sources obtainable from agro-energy sector. With the aim to reduce competition for land with food crop, renewable energy must be obtained from crop residuals or from energy crops cultivated in marginal soils not suitable for food crops, such as polluted soils, marginal lands subjected to accelerated erosion or salinisation (Fiorentino et al., 2010; Fagnano et al., 2012, 2015; Impagliazzo, 2014).

Among the different biomass crops, one of the most interesting is giant reed (Arundo donax L.), because of its tolerance to different environmental stresses and its capacity to produce interesting amount of ligno-cellulosic biomass also in marginal areas (Angelini et al., 2005b; Fiorentino et al., 2013; Nassi o Di Nasso et al., 2013). It is a perennial, herbaceous plant, occurring over a wide range of climatic habitats and growing spontaneously and abundantly all over Italy. Usually it does not produce viable seeds because the pollen results unfruitful; consequently, the better propagation method, for this species, is the use of rhizomes (Christou et al., 2000).

It has a $\mathrm{C} 3$ photosynthetic cycle, but has high photosynthetic rate $\left(37 \mu\right.$ moli $\left.\mathrm{m}^{-2} \mathrm{~s}^{-1}\right)$ and productivity similar to $\mathrm{C} 4$ species (Rossa et al., 1998; Christou, 2001).

The average biomass yield in Italy ranges between 21 and $51 \mathrm{t} \mathrm{ha}^{-1}$ under medium-low supply of nitrogen (N) (100-120 kg $\mathrm{ha}^{-1} \mathrm{year}^{-1}$ ) and water (from no irrigation to $75 \%$ evapotranspiration restitution) (Angelini et al., 2005a, 2005b, 2009; Cosentino et al., 2006; Mantineo et al., 2009).

It can grow in all types of soils, from clay to sandy, with presence or not of rocks, with soil $\mathrm{pH}$ ranging from 5 to 8.7 (Di Tomaso, 1998) and tolerate salinity and water stress (Lewandosky et al., 2003).

The lignocellulosic biomass of giant reed represents an interesting source of cellulose for the production of paper (Ververis et al., 2004), rayon (Facchini, 1941), second-generation ethanol and biopolymers (Williams and Biswas, 2010), biogas production (Dragoni et al., 2015), for the cultivation of oleaginous yeasts for biodiesel production (Pirozzi et al., 2010, 2015). 
As regards the relations between yield and mineral fertilisation, there are contrasting results (Dalianis et al., 1994; Christou et al., 1999; Monti and Venturi, 1999; Cosentino et al., 2005), maybe due to the different fertility levels or to the different age of standings. Plant growth analysis is a tool able to better analyse plant behaviour. Moreover, it is an explanatory, holistic and integrated approach to study and describe the various processes of plant system (i.e. plant morphology, physiology and phenology), with the advantage of use simple primary data such as weights and leaf area (Evans, 1972; Causton and Venus, 1981; Hunt, 1990).

The main objective of this research was to improve the knowledge about growth and yield of giant reed, under different pedoclimatic conditions.

\section{Materials and methods}

\section{Environmental aspects of study areas}

The experimental site of Sant'Angelo dei Lombardi (AV, Italy) (SA) was located in the experimental farm Centro Rotary of the Department of Agriculture of the Naples University Federico II, in the inland hills of Campania region $\left(40^{\circ} 92^{\prime} \mathrm{N}, 15^{\circ} 12^{\prime} \mathrm{E}, 700 \mathrm{~m}\right.$ asl).

This field is characterised by clay soils with low content of organic matter and a 10\% slope (Table 1). The climate is typical of inland hills of Campania region, with cold winter and frequent snowfalls, and hot and dry summer. Driest months are June, July and August and the rainfall events are concentrated in the autumn and winter months with the presence of frequently extreme events (thunderstorms).

During the long-term field experiment (2004 to 2013), the average annual temperature was $12^{\circ} \mathrm{C}$, with an absolute minimum temperature ranging between -2 and $-10^{\circ} \mathrm{C}$ and a maximum between 24.0 and $37^{\circ} \mathrm{C}$ (Table 1). The annual rainfall was 1079 $\mathrm{mm}$ and the reference evapotranspiration (Hargreaves et al., 1985) was $929 \mathrm{~mm}$ on the average.

The experimental site of Bellizzi (SA, Italy) (BL) was located in the experimental farm Torre Lama of the University of Naples Federico II, $\left(40^{\circ} 37^{\prime} \mathrm{N}, 14^{\circ} 58^{\prime} \mathrm{E}, 30 \mathrm{~m}\right.$ asl $)$ in the Sele alluvial plain.

The soil has silt-loam texture and low content organic matter and $\mathrm{N}$ (Table 1). The climatic conditions are typical of Mediterranean areas with temperate and rainy winter and hot and dry summer, the rainfall events are concentrated in the autumnwinter period, with the maximum peak in January and the minimum in July.

During the experimental period (2008-2013), the average annual temperature was $17^{\circ} \mathrm{C}$, with an absolute minimum temper- ature ranging between 0 and $-3^{\circ} \mathrm{C}$ and maximum between 35 and $37^{\circ} \mathrm{C}$ (Table 1). The annual rainfall was about $621 \mathrm{~mm}$ and the reference evapotranspiration was $1105 \mathrm{~mm}$ on the average.

The third field experiment was carried out in a private farm of Acerra plain (Campania region) (AC) $\left(40^{\circ} 60 \mathrm{~N}, 14^{\circ} 21^{\prime} \mathrm{E}, 21 \mathrm{~m}\right.$ asl), characterised by volcanic soils particularly suitable for intensive horticultural crop production. The soil texture is sandy-loam, with a sub alkaline $\mathrm{pH}$ and a high content of organic matter and $\mathrm{N}$ (Table 1). Moreover, the Regional Agency for Environmental Protection has classified this soil as not suitable for farming on the base of its cadmium contamination (Fiorentino et al., 2013).

The climate is that typical of the coastal plain with mild winters and frequent rainfall events during the autumn periods and with hot and dry summer. During the experimental period (20092012), the average annual temperature was about $16^{\circ} \mathrm{C}$, with the daily absolute minimum and maximum temperatures ranging between -3 and $-6^{\circ} \mathrm{C}$ and 37 and $42^{\circ} \mathrm{C}$, respectively (Table 1 ). The annual rainfall was $1060 \mathrm{~mm}$ and the reference evapotranspiration was $1264 \mathrm{~mm}$ on the average.

\section{Crop management}

At SA, seedbed preparation started in August 2003 with deep ripping $(60 \mathrm{~cm})$ followed by mouldboard ploughing $(40 \mathrm{~cm})$ and rotary hoeing $(20 \mathrm{~cm})$. Giant reed rhizomes were collected from wild stands of the same area. They were cut $(10 \mathrm{~cm}$ with at least three buds) and transplanted on February 2004 in $140 \mathrm{~m}^{2}(10 \times 14$ $\mathrm{m})$ plots at the density of $1 \times 1 \mathrm{~m}$. No irrigation was made and two doses of $\mathrm{N}$ fertilisation were compared (100 and $50 \mathrm{~kg} \mathrm{~N} \mathrm{ha}^{-1}$ from urea). At BL, soil preparation was made in autumn 2007 with deep ripping $(60 \mathrm{~cm})$ followed by soil milling $(20 \mathrm{~cm})$, pre-plant fertilisation of $150 \mathrm{~kg} \mathrm{ha}^{-1}$ of $\mathrm{K}_{2} \mathrm{O}$ (potassium sulphate) and $150 \mathrm{~kg} \mathrm{ha}^{-1}$ $\mathrm{P}_{2} \mathrm{O}_{5}$ (triple superphosphate). Giant reed rhizomes were collected from wild stands of this area. They were cut $(10 \mathrm{~cm}$ with at least three buds), planted on February 2008 at 10-20 cm of soil depth, at the density of $1 \times 1 \mathrm{~m}$ and transplanted in $528 \mathrm{~m}^{2}(16 \times 333 \mathrm{~m})$ plots. No irrigation was made and two doses of $\mathrm{N}$ fertilisation were compared (100 and $50 \mathrm{~kg} \mathrm{~N} \mathrm{ha}^{-1}$ from urea). Plants were watered only after transplanting (April 2008) in order to ensure good root contact with the soil. At AC giant reed rhizomes were collected from the farm Torre Lama of the University of Naples Federico II. They were cut (10 cm with at least three buds), planted on April 2009 at $10-20 \mathrm{~cm}$ of soil depth, at the density of $0.60 \mathrm{~m} \times 0.60 \mathrm{~m}$ and transplanted in $132 \mathrm{~m}^{2}(6 \times 22 \mathrm{~m})$ plots. No irrigation was made and two doses of compost ( 0 and $20 \mathrm{tha}^{-1}$, corresponding to $130 \mathrm{~kg} \mathrm{~N} \mathrm{ha}^{-1}$ ) were compared with the aim to study the effect of compost on pollutant phytoextraction (Fiorentino et al., 2013).

Table 1. Soil and climatic characteristics of experimental sites.

\begin{tabular}{|c|c|c|c|c|c|c|c|c|c|c|c|}
\hline \multirow[t]{3}{*}{ Site } & \multicolumn{3}{|c|}{ Soil texture $(0-40 \mathrm{~cm})$} & \multicolumn{3}{|c|}{$\begin{array}{l}\text { Soil chemical } \\
\text { characteristics }\end{array}$} & \multicolumn{5}{|c|}{$\begin{array}{c}\text { Climatic information over the years } \\
\text { of the long term experiment }\end{array}$} \\
\hline & \multirow{2}{*}{$\begin{array}{c}\text { Sand (\%) } \\
(2-0.05 \mathrm{~mm})\end{array}$} & \multirow{2}{*}{$\begin{array}{c}\text { Silt }(\%) \\
(0.05-0.002 \mathrm{~mm})\end{array}$} & \multirow{2}{*}{$\begin{array}{c}\text { Clay }(\%) \\
(<0.002 \mathrm{~mm})\end{array}$} & \multirow[t]{2}{*}{$\mathrm{pH}$} & \multirow{2}{*}{$\begin{array}{l}\text { OM } \\
(\%)\end{array}$} & \multirow{2}{*}{$\begin{array}{l}\text { total N } \\
\left(\mathrm{g} \mathrm{kg}^{-1}\right)\end{array}$} & \multicolumn{3}{|c|}{ Temperature $\left(C^{\circ}\right)$} & \multirow{2}{*}{\multicolumn{2}{|c|}{$\begin{array}{l}\text { Rainfall } \mathrm{ET}_{0} \\
\text { Annual average } \\
\left(\mathrm{mm} \text { year }{ }^{-1}\right)\end{array}$}} \\
\hline & & & & & & & $\begin{array}{l}\text { Annual } \\
\text { average }\end{array}$ & $\begin{array}{l}\text { Absolute } \\
\text { minimum }\end{array}$ & $\begin{array}{l}\text { Absolute } \\
\text { maximum }\end{array}$ & & \\
\hline $\mathrm{SA}^{*}$ & 37.1 & 24.8 & 38.1 & 8.1 & 1.1 & 0.9 & $11.8( \pm 0.6)$ & -10 & 35.5 & $1050( \pm 263)$ & $916( \pm 62)$ \\
\hline $\mathrm{BL}^{\circ}$ & 29.3 & 43.3 & 27.5 & 7.3 & 1.9 & 1.2 & $17.0( \pm 0.2)$ & -2.6 & 37.4 & $651( \pm 135)$ & $1105( \pm 14)$ \\
\hline $\mathrm{AC}^{\#}$ & 58.5 & 25.1 & 16.3 & 7.7 & 2.9 & 1.8 & $16.3( \pm 0.2)$ & -5.8 & 41.9 & $1060( \pm 176)$ & $1264( \pm 47)$ \\
\hline
\end{tabular}

OM, organic matter; $\mathrm{N}_{\text {tot }}$, total organic nitrogen; $\mathrm{ET}_{0}$, evapotranspiration; SA, Sant’Angelo dei Lombardi; BL, Bellizzi; AC, Acerra. *Soil sampled in October 2004 before planting, climatic period (2004-2013); ${ }^{\text {Soil sam- }}$ pled in February 2008 before planting, climatic period (2008-2013); " soil sampled in April 2009 before planting, climatic period (2009-2013). 


\section{Crop and soil monitoring}

Yield data refer to standings of 10 years at SA (2004-2013), 6 at BL (2008-2013) and 4 at AC (2009-2012). Harvests of the aboveground biomass were manually made, on sampling areas of $10 \mathrm{~m}^{2}$, in the winter after each growing cycle (February 2014 at SA, and BL and February 2013 at AC). The plants were cut at about $5 \mathrm{~cm}$ from the ground with subsequent separation in leaves and in culms for the determination of the fresh weight. Sub-samples of each fraction was oven-dried at $65^{\circ} \mathrm{C}$ until constant weight for determining the percentage of dry matter. In the last year, subsamples of leaves and culms were milled (4 mm) with Knife Mill SM 300 [Retsch Italy S.r.l., Torre Boldone (BG), Italy] and sent to the laboratory for the determination of the content in organic $\mathrm{N}$ (Kjeldahl method). In the same dates, soil samples of two layers $(0-20,20-40 \mathrm{~cm})$ were collected for measuring organic $\mathrm{N}$ and organic $\mathrm{C}$ content by the Kjeldahl and Walkley-Black methods, respectively.

\section{Crop growth analysis}

Crop growth analysis was made on the last growth cycle that corresponded to the $10^{\text {th }}$ growth period at $\mathrm{SA}, 6^{\text {th }}$ at BL and $4^{\text {th }}$ at AC. For the three sites, crop sampling began 10 days after crop regrowth. For each date, a sampling area of $1 \mathrm{~m}^{2}$ repeated 3 times was chosen. Aboveground fresh biomass (leaves and stems) and leaf area were measured. Samples of each fraction were oven-dried at $65^{\circ} \mathrm{C}$ until constant weight for determining the percentage of dry matter. The leaf area was measured by LI-3100C Area Meter (LICOR, Lincoln, NB, USA). The collected data have been used to calculate the following indices: dry weight (DW): quantity of dry matter per unit area $\left(\mathrm{g} \mathrm{m}^{-2}\right)$; leaf area index (LAI): ratio between leaf area and ground area $\left(\mathrm{m}^{2} \mathrm{~m}^{-2}\right)$; leaf area duration (LAD): the integration of leaf area over the growth period.

This last is the average value of the time intervals of LAI, derived from the following expression:

$$
\mathrm{LAD}=(\mathrm{LAI} 2+\mathrm{LAI} 1) *\left(\mathrm{t}_{2}-\mathrm{t}_{1}\right) / 2
$$

where, LAD $=$ leaf area duration $\left(\mathrm{m}^{2} \mathrm{~m}^{-2} \mathrm{~d}\right), \mathrm{LAI} 1, \mathrm{LAI} 2=\mathrm{LAI}$ at days $t_{1}$ and $t_{2}$ respectively, and $t_{1}, t_{2}=$ days of the year in the two sampling dates.

\section{Statistical analysis}

All data were subjected to analysis of variance by using the software MSTAT-C (Crop and Soil Science Department, Michigan State University, East Lansing, MI, USA). A split plot randomised block design with 2 factors, locations (main factor) and fertilisation (sub-factor) was used. All means were separated using LSD test for a $\mathrm{P} \leq 0.05(*)$ and $\mathrm{P} \leq 0.01(* *)$. The data of growth analysis were subjected to linear regression analysis.

\section{Results}

\section{Above-ground biomass yield}

The trend of biomass yield over the years (Figure 1) was similar in the three sites, with increasing values in the first 3-4 years. Yield levels are very similar in the fields of SA and BL, with peaks of 20 and $25 \mathrm{tha}^{-1} \mathrm{DW}$, while they were higher at $\mathrm{AC}$ where yield reached $35 \mathrm{t} \mathrm{ha}^{-1} \mathrm{DW}$ in the $4^{\text {th }}$ year. The effect of the higher dose of fertiliser was significant at BL $(+15.6 \%$ on the average) and SA $(+16 \%$ on the average); of course in the highly fertile soil of $\mathrm{AC}$, compost fertilisation did not have effect of crop yield.

\section{Crop nitrogen uptake}

Nitrogen uptake was significantly higher $\left(131.5 \mathrm{~kg} \mathrm{ha}^{-1}\right)$ at $\mathrm{AC}$, according to the greater yield, with $\mathrm{N}$ content in the culms and

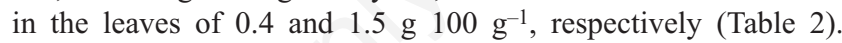
Nitrogen uptake was very much lower at SA and BL (65.7 and 73.1 $\mathrm{kg} \mathrm{ha}^{-1}$ respectively).

\section{Carbon and nitrogen balance during the crop periods in the three sites}

The soil organic carbon content (SOC) was evaluated in the topsoil $(0-20 \mathrm{~cm})$ for the period 2004-2013 at SA, 2008-2013 at BL and 2009-2012 at AC (Table 3).

Table 2. Crop nitrogen content and uptake in the three sites in the year of crop growth analysis.

\begin{tabular}{lccc}
$\begin{array}{c}\text { Total N uptake }\left(\mathrm{kg} \mathrm{ha}^{-1}\right) \\
\text { Culms }\end{array}$ & $\begin{array}{c}\text { N content } \\
\left(\mathrm{g} 100 \mathrm{~g}^{-1}\right) \\
\text { Leaves }\end{array}$ \\
Site & $65.7^{\mathrm{b}}$ & 0.3 & $0.9^{\mathrm{b}}$ \\
SA & $73.1^{\mathrm{b}}$ & 0.3 & $1.6^{\mathrm{a}}$ \\
BL & $131.5^{\mathrm{a}}$ & 0.4 & $1.5^{\mathrm{a}}$ \\
AC & 90.12 & 0.3 & 1.3 \\
Mean & & & \\
\hline Significance & $\leq 0.01$ & $\mathrm{~ns}$ & $\mathrm{n}$ \\
Location & $\mathrm{ns}$ & $\mathrm{ns}$ & $\mathrm{ns}$ \\
Fertilisation & $\mathrm{ns}$ & $\mathrm{ns}$ & $\mathrm{ns}$ \\
Loc. $\times$ Fert. & &
\end{tabular}

N, nitrogen; SA, Sant'Angelo dei Lombardi; BL, Bellizzi; AC, Acerra; ns, not significant. a,bValues within a column with the same letters are not significantly different at $\mathrm{P}<0.05$.

Table 3. Organic carbon content in the topsoil $(0-20 \mathrm{~cm})$ at planting and at harvest of the year of crop growth analysis.

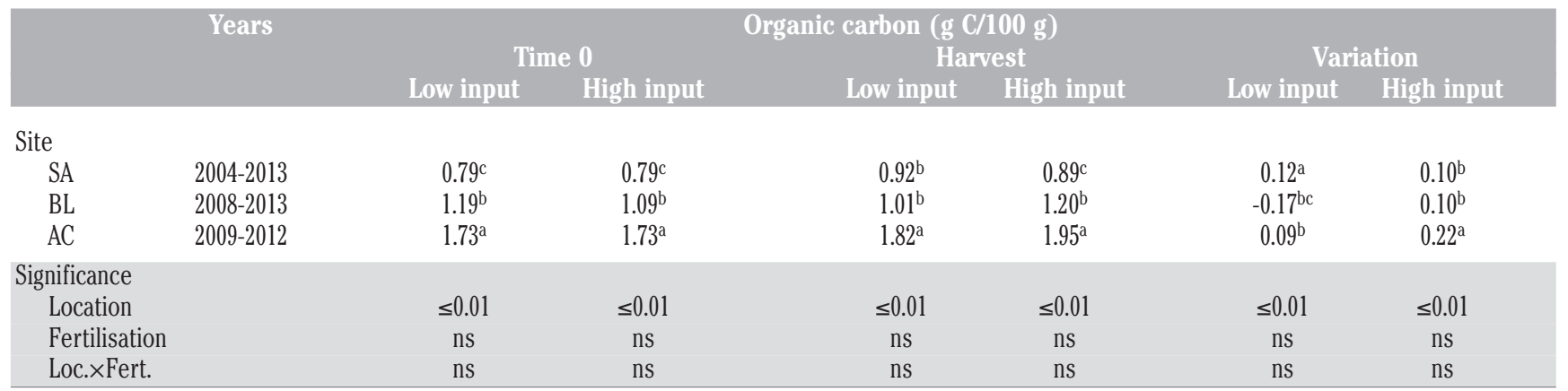

SA, Sant'Angelo dei Lombardi; BL, Bellizzi; AC, Acerra; ns, not significant. a,cValues within a column with the same letters are not significantly different at $\mathrm{P}<0.05$. 
At SA, the 2 fertiliser doses (N50 and N100) showed the same

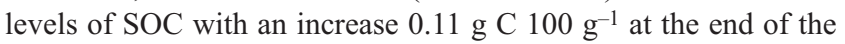
$10^{\text {th }}$ crop cycle, on the average, corresponding to a $14 \%$ increment. The increase of organic $\mathrm{N}$ during the 9 years was $0.32 \mathrm{~g} \mathrm{~N} \mathrm{~kg}^{-1}$ soil corresponding to a $36 \%$ increment (Table 4 ).

In contrast, at BL after 6 years of copping period, organic carbon increased only with the highest dose of $\mathrm{N}\left(100 \mathrm{~kg} \mathrm{ha}^{-1}\right)$, while with the lowest dose of fertiliser, there was a depletion of the reserves of soil organic carbon. Organic $\mathrm{N}$ in the topsoil did not changed with the lowest dose of fertiliser, while increased by $11 \%$ with the dose of $100 \mathrm{~kg} \mathrm{~N} \mathrm{ha}^{-1}$.

Finally, at AC inputs of compost ( $\left.3.5 \mathrm{t} \mathrm{C} \mathrm{ha}^{-1}\right)$, after 4 years significantly contributed to the SOC in the top-soil, increasing the

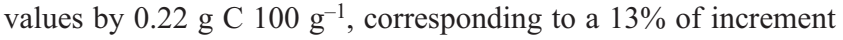
(Table 3), while in the not fertilised plots, SOC increased in 4 years

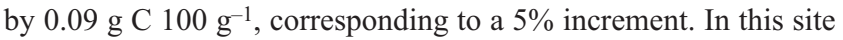
the increase of organic $\mathrm{N}$ was very limited in both the fertiliser levels, with an increase of $0.16 \mathrm{~g} \mathrm{~kg}^{-1}$, on the average, corresponding to a $9 \%$ increment (Table 4).

\section{Growth analysis}

\section{Above-ground biomass}

The growth rates of the aboveground biomass were similar in SA and BL and much higher in AC (Figure 2).

At SA (Figure 2A) there was an effect of fertilisation dose, with values $14 \%$ higher on the average with the dose of $100 \mathrm{~kg} \mathrm{~N}$ $\mathrm{ha}^{-1}$. The seasonal peak of biomass accumulation was reached in November $\left(2065 \mathrm{~g} \mathrm{~m}^{-2} \mathrm{DW}\right.$ and $1741 \mathrm{~g} \mathrm{~m}^{-2} \mathrm{DW}$, respectively for N100 and N50). At BL (Figure 2B) the effect of fertiliser increased from June until November. Also in this site the peak of biomass accumulation was attained in November $\left(1875 \mathrm{~g} \mathrm{~m}^{-2} \mathrm{DW}\right.$ and 1209 $\mathrm{g} \mathrm{m}^{-2}$ DW respectively for N100 and N50).

The highest values of accumulation of above-ground biomass in absolute terms during the growing season, as already highlighted for yield, were recorded at AC site (Figure 2C) with a peak of production in September and with a reduced effect of fertiliser doses (3576 $\mathrm{g} \mathrm{m}^{-2} \mathrm{DW}$ on the average).

\section{Leaf area index}

LAI pattern (Figure 3) was similar to that of biomass, with similar trend in SA and BL and higher values in AC. The peak was attained in July at SA (Figure 3A), September at BL (Figure 3B) and $\mathrm{AC}$ (Figure 3C).

The maximum values at SA were higher than at $\mathrm{BL}$, with the reduced $\mathrm{N}$ fertiliser dose $\left(3.8\right.$ and $2.6 \mathrm{~m}^{2} \mathrm{~m}^{-2}$ respectively, corresponding to a $46 \%$ difference). The highest dose of $\mathrm{N}$ fertiliser reduced the differences between the two sites $\left(4.2\right.$ and $3.5 \mathrm{~m}^{2} \mathrm{~m}^{-2}$ respectively at SA and BL, corresponding to a $20 \%$ difference).

The maximum values of LAI were much higher in AC site (10 $\mathrm{m}^{2} \mathrm{~m}^{-2}$ on the average).
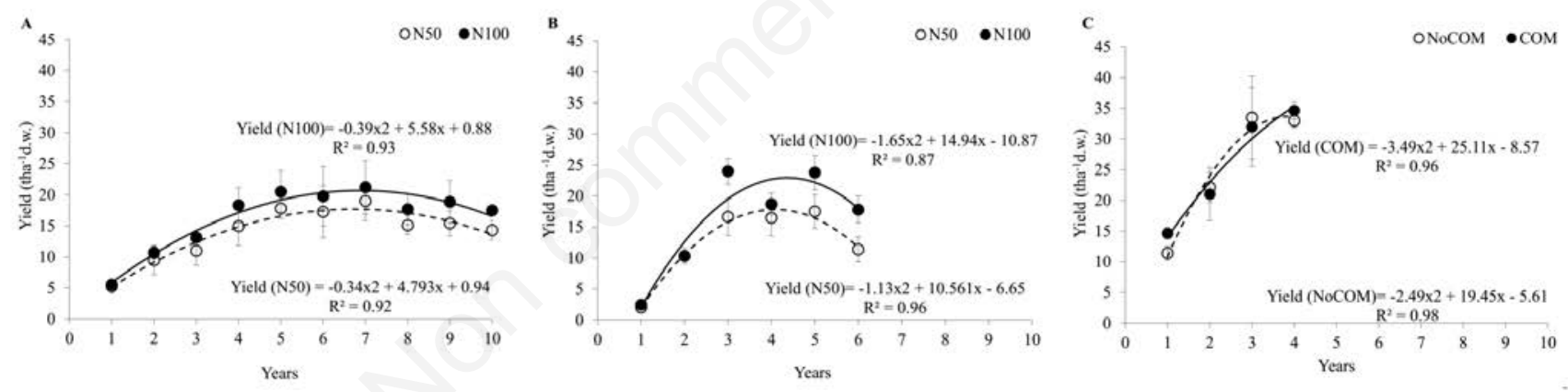

Figure 1. Above-ground giant reed biomass yield over the long-term experiment in the three experimental sites: A) Sant'Angelo dei Lombardi; B) Bellizzi; C) Acerra. Bars indicate standard errors ( $\mathbf{n}=3)$.

Table 4. Organic nitrogen content in the topsoil $(0-20 \mathrm{~cm})$ at planting and at harvest of the year of crop growth analysis.

\begin{tabular}{|c|c|c|c|c|c|c|c|}
\hline \multirow[t]{2}{*}{ 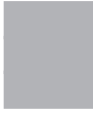 } & \multirow[t]{2}{*}{ Years } & \multicolumn{2}{|c|}{ Time 0} & \multicolumn{2}{|c|}{$\begin{array}{l}\text { Organic } \\
\text { Harvest }\end{array}$} & \multicolumn{2}{|c|}{ Variation } \\
\hline & & Low input & High input & Low input & High input & Low input & High input \\
\hline \multicolumn{8}{|l|}{ Site } \\
\hline SA & 2004-2013 & $0.81^{\mathrm{b}}$ & $0.81^{b}$ & $1.16^{\mathrm{b}}$ & $1.09^{c}$ & 0.35 & 0.28 \\
\hline BL & 2008-2013 & $1.14^{\mathrm{ab}}$ & $1.22^{\mathrm{ab}}$ & $1.14^{\mathrm{b}}$ & $1.35^{\mathrm{b}}$ & 0.00 & 0.13 \\
\hline $\mathrm{AC}$ & 2009-2012 & $1.75^{\mathrm{a}}$ & $1.75^{\mathrm{a}}$ & $1.92^{\mathrm{a}}$ & $1.90^{\mathrm{a}}$ & 0.15 & 0.17 \\
\hline \multicolumn{8}{|c|}{ Significance } \\
\hline Loc & & $\leq 0.01$ & $\leq 0.01$ & $\leq 0.01$ & $\leq 0.01$ & ns & ns \\
\hline Fert & & ns & ns & ns & ns & ns & ns \\
\hline Loc & & ns & ns & ns & ns & ns & ns \\
\hline
\end{tabular}

N, nitrogen; SA, Sant'Angelo dei Lombardi; BL, Bellizzi; AC, Acerra; ns, not significant. a,bValues within a column with the same letters are not significantly different at $\mathrm{P}<0.05$. 
The leaf area duration (LAD) was lower at BL (677 vs 477 $\mathrm{m}^{2} \mathrm{~m}^{-2} \times$ days, for the two $\mathrm{N}$ doses respectively), higher at SA ( 800 vs $611 \mathrm{~m}^{2} \mathrm{~m}^{-2} \times$ days, for the two $\mathrm{N}$ doses respectively) and very much higher at $\mathrm{AC}\left(1410 \mathrm{~m}^{2} \mathrm{~m}^{-2} \times\right.$ days, on the average $)$.

\section{Discussion}

\section{Biomass yield}

The trend of biomass yield during the years confirms the results reported by Angelini et al. (2009), who identified three phases in growth of giant reed: an increasing phase until the $3^{\text {rd }}-4^{\text {th }}$ year, a stationary phase from the $4^{\text {th }}$ to the $8^{\text {th }}$ year and a decreasing phase from the $9^{\text {th }}$ to the $12^{\text {th }}$ year of growth.

The different fertility levels and the environmental constraints influenced the growth and yield of giant reed and also the effect of fertilisers.

The higher yield was obtained at AC, already in the first year of growth. These results are in line with those reported by Cosentino et al. (2006) who compared 39 clones of common reed grown in southern Italy whose yield in the first and second year amounted to 11 - $22 \mathrm{t} \mathrm{ha}^{-1}$ DW Of course the effect of compost fertilisation was not significant in this site, both for the well-known very high fertility levels of the volcanic soils of Campania plain (Di Vito et al., 2013) and for the slow mineralisation rate of composted organic matter that make this fertiliser unable to guarantee $\mathrm{N}$ available for crops, as already noticed in previous trials made with the same compost in the same environment (Alluvione et al., 2013). The effect of compost on pollutant phytoextraction was discussed by Fiorentino et al. (2013). Lower yield was recorded in the other two sites, both for the lower fertility of soils and for environmental constraints: winter cold at SA and the extreme drought at BL. At SA, yield levels of biomass and uptake of $\mathrm{N}$ were similar to those obtained in Italy on marginal lands (Nassi o Di Nasso et al., 2010, 2011b, 2013), but lower than those reported in most fertile environments (Angelini et al., 2005a; Cosentino et al., 2006).

In this site, a $16 \%$ of yield increase was obtained with $100 \mathrm{~kg}$ $\mathrm{ha}^{1}$ of $\mathrm{N}$ on the average, with increasing differences over the time. Therefore, the restitution of $\mathrm{N}$ uptake with fertilisation is necessary for allowing good yield levels and for not depleting native soil resources. Among the compared sites, the lowest yield was obtained at $\mathrm{BL}$, in which a decreasing trend is evident starting from the $5^{\text {th }}$ year, maybe mainly due to water limitations that do not allow high photosynthetic rates and assimilate availability for the reservoir organs (i.e. rhizomes), thus limiting the regrowth in the following years (Mann et al., 2013; Sanchez et al., 2015).

\section{Carbon and nitrogen variations}

The giant reed cropping system can have a positive effect on the storage of $\mathrm{C}$ in the soil thanks to the absence of soil tillage and abundance of crop residues that every year return to the soil. Compost fertilisation before planting has led to a significant

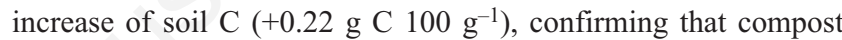
fertilisation can contribute to climate change mitigation (Alluvione et al., 2013). This increase corresponds to $5.7 \mathrm{t} \mathrm{C} \mathrm{ha}^{-1}$ (18.7 t $\mathrm{CO}_{2}$
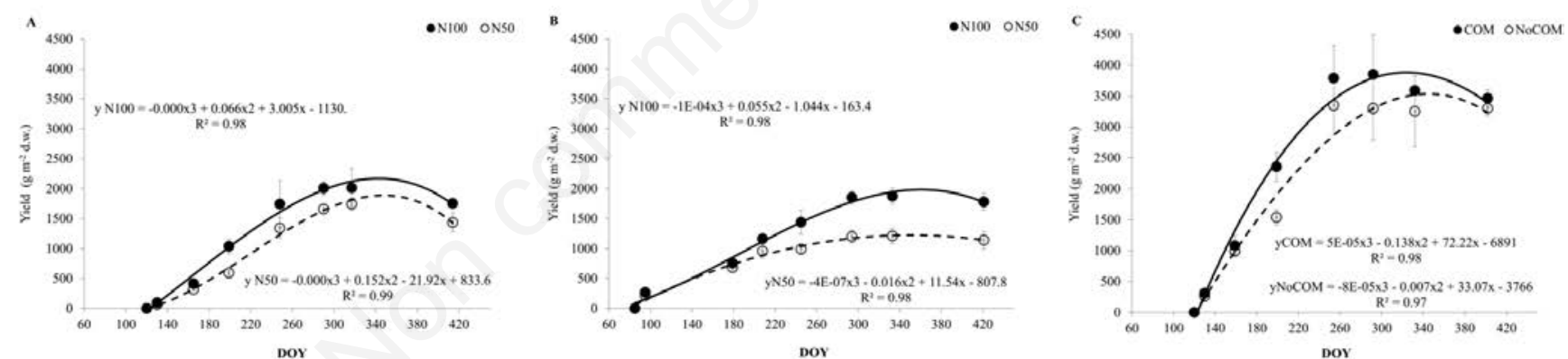

Figure 2. Development of above-ground biomass ( $\mathrm{gm}^{-2}$ dry weight) in the last crop cycle. A) Sant'Angelo dei Lombardi (10 $\left.{ }^{\text {th }}\right)$; $B$ ) Bellizzi $\left(6^{\text {th }}\right)$; C) Acerra $\left(4^{\text {th }}\right)$. Bars indicate standard errors $(n=3)$.


Figure 3. Leaf area index $\left(\mathrm{m}^{2} \mathrm{~m}^{-2}\right)$ in the last growing season. A) Sant'Angelo dei Lombardi $\left(10^{\text {th }}\right)$; B) Bellizzi $\left(6^{\text {th }}\right)$; C) Acerra $\left(4^{\text {th }}\right)$. Bars indicate standard errors $(n=3)$. 
$\mathrm{ha}^{-1}$ ) and considering that the compost provided an initial input of $3.5 \mathrm{t} \mathrm{C} \mathrm{ha}^{-1}$, these results indicate that, in addition to the contribution of stabilised organic matter, soil $\mathrm{C}$ increase may be due to the contribution of leaf fall, root exudates and turnover, and soil $\mathrm{C}$ protection by the litter effect and by the absence of soil tillage (Fagnano et al., 2015).

This is also confirmed by the higher increases of soil $\mathrm{C}$ that have been recorded in the more productive conditions (Swinnen et al., 1995). Organic $\mathrm{N}$ into the topsoil was higher at SA, mainly because the environmental constraints (summer drought and winter cold) may have reduced the mineralisation thus enhancing its accumulation in soil organic matter, as already reported by Fagnano et al. (2015). At BL site, C and $\mathrm{N}$ variation were null or negative with lower fertiliser doses, thus confirming that fertilisation rate that not compensate $\mathrm{N}$ uptake by crops is not sustainable not only for yield levels and stability but also for soil fertility.

\section{Growth analysis}

Giant reed in all the three sites have a growing season starting in March-April and ending in October-November, confirming what observed by Nassi or Di Nasso et al. (2011a). Maximum values of biomass and leaf area index recorded at AC in the autumn period were similar to those reported by Nassi o Di Nasso et al. (2011a) and from Triana et al. (2015), while the values were lower in the other two sites thus confirming their lower fertility levels. LAD increased with fertilisation by $42 \%$ at $\mathrm{BL}, 31 \%$ at SA, thus proving to be a good indicator of productive potential of cropping systems: correlation between biomass yield and LAD was highly significant $(P \leq 0.001)$ (Figure 4). This could be related to the higher intercepted PAR as reported by Ceotto et al. (2013).

On the average, LAD values calculated in 2013 were 1415 , $706,477 \mathrm{~m}^{2} \mathrm{~m}^{-2} \times \mathrm{d}$ at AC, SA, BL respectively and they were very higher than those of high productivity crops such as maize. In particular, LAD values measured in Campania Region were 353 $\mathrm{m}^{2} \mathrm{~m}^{-2} \times \mathrm{d}$ (Basile and Terribile, 2008); in international literature (Bukhsh et al., 2010) very much lower values are reported for maize $\left(169 \mathrm{~m}^{2} \mathrm{~m}^{-2} \times \mathrm{d}\right)$. These differences are not due to maximum values of LAI, that were not different from our data, but to the higher duration of vegetative period and thus of photosynthetic activity of giant reed: 284 days on average for $v s$ 131-140 days of maize (FAO class 700).



Figure 4. Linear regression: leaf area duration $v s$ above-ground biomass yield.

\section{Conclusions}

Giant reed (Arundo donax L.) confirms its adaptability to low fertility soils, allowing interesting biomass yield also in marginal lands. Nevertheless, $\mathrm{N}$ uptake, even if lower $\left(65-130 \mathrm{~kg} \mathrm{ha}^{-1}\right)$ than other high-yielding crops, has to be compensated with fertilisation for avoiding soil nutrient depletion, with the aim to guarantee the sustainability of this cropping system. Its cultivation had a favourable environmental impact, thanks to the improvement in soil fertility (soil organic matter and $\mathrm{N}$ increase) and to mitigation of climate change ( $\mathrm{C}$ storage in the soil) due to both the contribution of leaf fall, root exudates and turnover and to soil $\mathrm{C}$ protection by the litter effect and by the absence of soil tillage. In marginal soils of Southern Italy, this crop also confirms the presence of an increasing trend during the first 3-4 years, then followed by a constant phase whose duration depends on environmental constraints and sustainability of cropping systems (i.e. fertilisation). High productivity levels of this crop are related to the extremely high duration of the vegetative period (from March to November in Mediterranean area), well expressed by LAD that is more than double as compared with other high-yielding crops like maize.

\section{References}

Alluvione F, Fiorentino N, Bertora C, Zavattaro L, Fagnano M, Quaglietta Chiarandà F, Grignani C, 2013. Short-term crop and soil response to $\mathrm{C}$-friendly strategies in two contrasting environments. Eur. J. Agron. 45:114-23.

Angelini GL, Ceccarini L, Bonari E, 2005a. Biomass yield and energy balance of giant reed (Arundo donax L.) cropped in central Italy as related to different management practices. Eur. J. Agron. 22:375-89.

Angelini GL, Ceccarini L, Nassi o Di Nasso N, Bonari E, 2005 b. Long term evaluation of biomass production of giant reed (Arundo donax L.) to different fertilisation input, plant density and harvest time in a Mediterranean environment. In: Grassi A, Maniatis K. (eds.), Proc. of the $14^{\text {th }}$ European Biomass Conference and Exhibition, Paris, October 17-21, pp. 141-4.

Angelini LG, Ceccarini L, Nassi o Di Nasso N, Bonari E, 2009. Comparison of Arundo donax L. and Miscanthus $\times$ giganteus in a long-term field experiment in Central Italy: analysis of productive characteristics and energy balance. Biomass Bioen. 33:635-43.

Basile A, Terribile F, 2008. La ricerca sull'inquinamento da nitrati nei suoli campani: un approccio modellistico nella gestione agro-ambientali. Regione Campania Ed., Naples, Italy.

Bukhsh MAAHA, Ahmad R, Malik AU, Hussain S, Ishaque M, 2010. Agro-physiological traits of three maize hybrids as influenced by varying plant density. J. Anim. Plant Sci. 20:34-9.

Causton DR, Venus JC, 1981. The biometry of plant growth. Edward Arnold, London, UK.

Ceotto E, Di Candilo M, Castelli F, Badeckc F, Rizza F, Soave C, Volta A, Villani G, Marletto V, 2013. Comparing solar radiation interception and use efficiency for the energy crops giant reed (Arundo donax L.) and sweet sorghum (Sorghum bicolor L. Moench). Field Crops Res. 149:159-66.

Christou M, 2001. Giant reed in Europe. In: Proc. $1^{\text {th }}$ World Conf. on Biomass for Energy and Industry, Seville, Spain, 5-9 June 2000, pp. 2089-91.

Christou M, Mardikis M, Alexopoulou E, 2000. Propagation mate- 
rial and plant density effects on the Arundo donax yields. In: Biomass for energy and industry: Proc. $1^{\text {th }}$ World Conf., Seville, Spain, 5-9 June 2000, pp. 1622-8.

Christou M, Papavassiliou D, Efthimia A, Artemios C, 1999. Comparative studies of two potential energy crops in Greece. In: Biomass for energy and industry: Proc. 10 $0^{\text {th }}$ European Conf. and Technology Exhibition, Wurzburg, Germany 8-11 June 1999, pp. 935-8.

Cosentino S, Foti S, Venturi G, Giovanardi R, Copani V, Mantineo M, D’Agosta G, Bezzi G, Mazzocco T, 2005. Colture erbacee annuali e poliennali da biomassa per energia di possibile coltivazione in Italia. Agroindustria 1:35-48.

Cosentino SL, Copani V, D’Agosta GM, Sanzone E, Mantineo M, 2006. First results on evaluation of Arundo donax L. clones collected in Southern Italy. Ind. Crops Prod. 23:212-22.

Dalianis C, Sooter C, Cristou M, 1994. Growth and biomass productivity of Arundo donax and Miscanthus sinensis x giganteus. In: Proc. of $8^{\text {th }}$ European Community Conference on Biomass for Energy, Environment Agriculture and Industry, Vienna, 3-5 October 1994, pp. 575-82.

Di Tomaso JM, 1998. Biology and ecology of giant reed. In: Bell, Carl E. (eds.) Arundo and saltcedar: the deadly duo: Proc. of a Workshop on Combating the torea from arundo an saltcedar, Ontario, Canada, 17 June 1998, pp. 1-5.

Di Vito MA, Castaldo N, de Vita S, Bishop SJ, Vecchio G, 2013. Human colonization and volcanic activity in the eastern Campania Plain (Italy) between the Eneolithic and Late Roman periods. Quatern. Int. 303:132-41.

Dragoni F, Ragaglini G, Corneli E, Nassi o Di Nasso N, Tozzini C, Cattani S, Bonari E, 2015. Giant reed (Arundo donax L.) for biogas production: land use saving and nitrogen utilisation efficiency compared with arable crops. Ital. J. Agron. 10:192201.

Evans GC, 1972. The quantitative analysis of plant growth. UC Press, Berkeley, CA, USA.

Facchini P, 1941. La canna gentile per la produzione della cellulosa nobile, l'impresa agricolo-industriale di Torviscova. Snia Viscosa, Milano, Italy.

Fagnano M, Boccia L, Pindozzi S, Infascelli R, Faugno S, 2012. Aree potenzialmente convertibili a colture energetiche: caso studio della Regione Campania. In: De Mastro G, Ventrella D, Verdini L. (eds.), Proc. of XLI Congress of the Italian Society of Agronomy, Bari, 19-21 September 2012, pp. 464-6.

Fagnano M, Impagliazzo A, Mori M, Fiorentino N, 2015. Agronomic and environmental impacts of giant reed (Arundo donax L.): results from a long-term field experiment in hilly areas subject to soil erosion. Bioenerg. Res. 8:415-22.

Fiorentino N, Fagnano M, Ventorino V, Pepe O, Zoina A, Impagliazzo A, Spigno P, 2013. Assisted phytoextraction of heavy metals: compost and Trichoderma effects on giant reed uptake and soil quality. Ital. J. Agron. 8:244-54.

Fiorentino N, Impagliazzo A, Ventorino V, Pepe O, Piccolo A, Fagnano M, 2010. Biomass accumulation and heavy metal uptake of giant reed on polluted soil in southern Italy. J. Biotechnol. 150:261.

Hargreaves GL, Hargreaves GH, Riley JP, 1985. Agricultural benefits for Senegal river basin. J. Irrig. Drain Eng. 111:113-24.

Hunt R, 1990. Basic growth analysis. University Park Press, Baltimore, MD, USA.

Impagliazzo A, 2014. Dinamica di crescita e risposta produttiva di una coltura da biomassa lignocellulosica (Arundo donax L.) in tre ambienti del territorio campano. Department of Agriculture, University of Naples Federico II, Naples, Italy.
Lewandosky I, Scurlock JMO, Lindvall E, Christou M, 2003. The development and current status of perennial rhizomatous grasses as energy crops in the US and Europe. Biomass Bioener. 25:335-61.

Mann JJ, Barney JN, Kyser GB, Do Tommaso JM, 2013. Miscanthus $\mathrm{x}$ giganteus and Arundo donax shoot and rhizome tolerance of extreme moisture stress. Global Change Biol. Bioen. 5:693-700.

Mantineo M, D'Agosta GM, Copani V, Patanè C, Cosentino SL, 2009. Biomass yield and energy balance of three perennial crops for energy use in the semi-arid Mediterranean environment. Field Crops Res. 114:204-13.

Monti A, Venturi P, 1999. Risposta della canna comune (Arundo donax L.) alla concimazione azotata. In: Bona S. (ed), Proc. XXXIII Congress of the Italian Society of Agronomy, Legnaro (PD), 20-23 September 1999.

Nassi o Di Nasso N, Angelini LG, Bonari E, 2010. Influence of fertilisation and harvest time on fuel quality of giant reed (Arundo donax L.) in central Italy. Eur. J. Agron. 32:219-27.

Nassi o Di Nasso N, Roncucci N, Bonari E, 2013. Seasonal dynamics of aboveground and belowground biomass and nutrient accumulation and remobilization in giant reed (Arundo donax L.): a three year study on marginal land. Bioenerg. Res. 6:725-36.

Nassi o Di Nasso N, Roncucci N, Triana T, Tozzini C, Bonari E, 2011a. Productivity of giant reed (Arundo donax L.) and miscanthus (Miscanthus x giganteus Greef et Deuter) as energy crops: growth analysis. Ital. J. Agron. 6:e22.

Nassi o Di Nasso N, Roncucci N, Triana T, Tozzini C, Bonari E, 2011b. Seasonal nutrient dynamics and biomass quality of giant reed (Arundo donax L.) and miscanthus (Miscanthus $\mathrm{x}$ giganteus Greef et Deuter) as energy crops. Ital. J. Agron. 6:e24.

Pirozzi D, Fiorentino N, Impagliazzo A, Sannino F, Yousuf A, Fagnano M, 2015. Lipid production from Arundo donax growth under different agronomical conditions. Renew. Energ. 77:456-62.

Pirozzi D, Yousuf A, Fagnano M, Mori M, Fiorentino N, Impagliazzo A, 2010. Lipids production by yeast grown on giant reed biomass. J Biotechnol. 150:167-8.

Rossa B, Tüffers AV, Naidoo G, von Willert DJ, 1998. Arundo donax L. (Poaceae) a C3 species with unusually high photosynthetic capacity. Bot. Acta 111:216-21.

Sanchez E, Scordia D, Lino G, Arias C, Cosentino SL, Nogues S, 2015. Salinity and water stress effects on biomass production in different Arundo donax L. clones. Bioener. Res. 8:1461-79.

Swinnen J, Vanveen JA, Merckx R, 1995. Carbon fluxes in the rhizosphere of winter wheat and spring barley with conventional vs integrated farming. Soil Biol. Biochem. 27:811-20.

Triana F, Nassi o Di Nasso N, Ragaglini G, Roncucci N, Bonari E, 2015. Evapotranspiration, crop coefficient and water use efficiency of giant reed (Arundo donax L.) and miscanthus (Miscanthus 3 giganteus Greef et Deu.) in a Mediterranean environment. GCB Bioen. 7:811-9.

Ververis C, Georghiou, Christodoulakis N, Santas P, Santas R, 2004. Fiber dimensions, lignin and cellulose content of various plant materials and their suitability for paper production. Ind. Crops Prod. 19:245-54.

Williams C, Biswas T, 2010. Commercial potential of giant reed for pulp, paper and biofuel production. Rural Industries Research and Development Corporation, Barton, Australia. 